\title{
FOREST RESEARCH IN CANADA DURING 1929
}

\section{BY J. H. WHITE}

NOVA SCOTIA.

1. The Dominion Forest Service had one party at work in Nova Scotia engaged on studies of reproduction and rate of growth for use in conjunction with the national forest inventory which is planned to extend through five years. This work was under way in four provinces in 1929 and necessarily embodied a large proportion of the activities of the Research Division. A report covering each project will be compiled by spring.

\section{NEW BRUINSWICK.}

1. The Dominion Forest Service maintained a second party here in connection with its national forest inventory, as noted above.

QUEBEC.

The Quebec Forestry Service reports the following:

10-Complete forest inventories by square miles made since 1923 . 26,805

$20-$ Working plans for regulation of cut on 26,800 square miles progressing. Technical inspection made in advance of operation for all cut by exception to the regulations.

30-Aerial photography 11,198 square miles. Air sketching 39,153 square miles.

$40-$ Study on taper and other factors affecting measurement of logs-400, 000 pieces.

50--Study of damage to young growth during logging.

$60-$ Establishment of sample plots in plantations and on limits.

$70-$ Co-operation in experiment on hemlock looper control.

80 -Reforestation of 1,000 acres of shifting sand and correction of ravines at St-Clet (Soulanges County).

90-Charcoal experiments with French portable kilns.

100 -Experiments on broadcast sowing on several square miles of brulés made together by the government and limitholders.

$110-$ Study of revision of scaling regulations and logging rules.

120-Salvage of frekilled lumber (close to 2 billion feet B.M.) removed since 1922 , or $1 / 7$ of total cut made during period.

130 -Closer inspection of logging operations and scaling (6.4 visits made to each camp during winter).

$140-$ Better hygienic conditions in camps.

$150-$ Good progress of Rangers School.

160-Good Progress of Laval Forestry School.

2. The Dominion Forest Service reports:

(1) Maintenance of one party on the national forest inventory. 
(2) Lake Edward Forest Experiment Station. Remeasurements of permanent sample plots established at Lac Tremblant in 1918, at Kenogami in 1924, and Lake Edward in 1918 and 1924. Deductions available some time during the winter.

(3) Study of silvical characteristics of spruce and fir in the area of Quebec so severely attacked by the hemlock looper, made in co-operation with the Entomological Branch and the Quebec Forest Service. The object was to formulate a plan for investigation of fundamental causes leading to a preponderance of fir reproduction.

3. The Technical Committee of The Association of Forest Engineers for the Province of Quebec reports a continuation of the two lines of study mentioned in the statement for 1928, viz.

(1) Examination of the feasibility of adopting for working plan surveys, a standard of accuracy in the results (as applied in Finland, Sweden and other countries), in place of a standard series of methods, or a standard schedule of cruising.

(2) Collection and examination of available silvicultural data with a view to a final analysis at a future date when sufficient information, bearing on silvicultural problems under various conditions met with in Quebec, justifies a conclusion as to the best general methods.

The report of the committee to the Association in December, 1929, contains the following conclusions as regards the first study:-

(a) The factors influencing the percentage cruise necessary to obtain a given degree of accuracy are: Variation in stand, size of unit on which estimate is required, comparative volumes of individual species. (b) Two variables have to be taken into account in determining the percentage cruise to arrive at a specified degree of accuracy in total quantities of all species combined, namely, the smallest area for which it is desired to obtain an estimate and the variation of the stand; that is, the larger the area and the lower the cordage per acre the lower the percentage of cruise necessary to obtain a given degree of accuracy. (c) If an estimate is required to show quantities by species to a given degree of accuracy, another variable factor is introduced, namely, the smaller the quantity of a species the higher the percentage of cruise required.

4. Price Brothers \& Co. Ltd. reports the following:

(1) Additional permanent sample plots, one-tenth acre in size, have been established in different types and age classes, in order to study the natural history of the forest, especially with regard to mortality and deterioration in mature stands.

(2) Additional permanent sample plots have been established in areas just prior to the logging operations, and the former plots have all been re. 
examined. These plots are being established to show the effect, silvicultural$1 y$, of the present system of logging.

(3) Artificial regeneration of burned-over forest. Fourteen acres of plantations, 242 acres broadcast sowing, and 2238 acres seedspot sowing.

(4) Investigation has been continued on the correlation of mill consumption with wood's scale.

(5) In co-operation with the Woodlands Section of the Canadian Pulp E Paper Association, sinkage studies on spruce, balsam and white birch, were continued.

5. Abitibi Power \& Paper Co., Ltd.--Ste Anne Division-reports:

(1) Permanent sample plots established for the purpose of determining growth of stands in various types on the Baie Ste. Paul watershed.

(2) Inventory and growth study work for the purpose of constructing a working plan for the seminary lands (228 sq. mi.) in the Ste Anne Division.

\section{ONTARIO.}

1. The Dominion Forest Service reports:

(1) One party on national forest inventory studies.

(2) Petawawa Forest Experiment Station. (a) Establishment of a number of permanent sample plots in connection with a demonstration woodlot. (b) Periodic remeasurement of plots. (c) Second thinning of one of the plots. (d) Photograph map of the Reserve practically completed.

(3) Publications and reports. (a) The bulletin "Form Class Volume Tables" is expected back from the press before the close of 1929. (b) Instructions for establishment of permanent sample plots as given in the Research Manual were revised and issued in mimeograph form. (c) Reports covering rate of growth surveys for Salmon river and Miramichi river drainage areas, New Brunswick, have been issued in mimeographed form. (d) Mimeographed report covering direct seeding investigation conducted in New Brunswick the last three years has been issued. (e) Brief memorandum descriptive of hardwood forests of New Brunswick issued. (f) Description of permanent sample plots at Lake Edward issued. (g) Article dealing with relative value of seedlings and transplants as found at Petawawa prepared for The Forestry Chronicle last March. Another article on girdling hardwoods to benefit conifers based on work at Lake Edward Station was submitted to The Chronicle in December. (h) Arrangements have been made for translation of items of particular value appearing in German, Swedish, or French. A number now in the Service library. 
2. The Ontario Forestry Branch reports:

(1) Nursery investigations. (a) St. Williams. Experiments in handling of black walnut fruits and poplar cuttings for reduction of mortality. (b) Orono. Seed bed fertilizer experiments, chiefly as regards losses due to fertilizer injury to germinating seedlings. Experiments looking to reduction of undersized stock in seed beds of spruce and cedar. Study of damping off control.

(2) Seeding and planting experiments. (a) St. Williams. Formation of 24 two-acre experimental plantations of the white spruce series, covering spacing, arrangement and mixing. Study of planting site preparation costs. (b) Midhurst. Establishment of 40 two acre experimental plantations involving 8 species. (c) Parry Sound. The combined seeding and planting experimental series was extended by 136 acres, sowing jack pine and planting white pine, as outlined in statement for 1928. Mortality counts in connection with the direct seeding experiments inaugurated in 1926 continued this year using strip method instead of plot counts. (d) Sudbury. Conifer seed crop record. Nairn experimental plantation, 200 acres of red and white pine. Small plantation of elm and maple.

(3) A continuation for the third season of a study of ground vegetation in relation to forest type classification in a white pine stand in Algonquin Park. Twenty-five one-quarter acre sample plots were laid out in two vegetative types within this stand and data taken for relating ground vegetation to tree growth.

(4) Forest conditions surveys. Timagami Provincial Forest-types, age classes and timber estimate, 400,000 acres. Wanapitei Provincial Forest, working plan data, 70,000 acres. Georgian Bay Provincial Forest, "shore site" delimitation, 325,000.

(5) Growth and yield investigation. The work in connection with the investigation of the growth and yield of spruce and jack pine in the Onaping lake district during the past year has been confined to the working up of the data gathered during the seasons of 1927 and 1928. This compilation is still in progress and a report is in course of preparation.

(a) It has been found that the relationship between diameter and height changes much less with increase in age in the case of spruce than with jack pine. With spruce the relationship changes somewhat more in swamps than on well-drained sites. The practical significance as regards timber estimating is that on well-drained ground one volume table based on diameter alone could be used for spruce stands with a considerable range of age; while in the case of jack pine, due to the greater variation in height of trees in the same diameter class but of different age-classes, height determinations are necessary and corresponding volume tables must be used.

Also the use of height as an index of site which is entirely satisfactory 
in the case of an intolerant species like jack pine is likely to be much less reliable in the case of a tolerant species like spruce. Some sort of special procedure would appear to be necessary in the case of spruce for the secur. ing of an average height to be used in computing the site index of a plot.

Likewise the change in the relationship between form quotient and diameter with change in age is much less in the case of spruce than with jack pine. In both cases there is a marked decrease in form quotient at any age as the size of tree increases.

(b) The diameter growth in different types and in different sites is being compared not merely for an average tree, but separately for every size of tree, so as to furnish a basis for estimating the future growth of the trees in each diameter class in young stands.

The growth rate of spruce, relative to diameter attained at a given age, would appear to be the same in pure stands as in mixtures with jack pine, to be largely independent of site, but lower in all pure coniferous stands than in spruce-paper birch stands.

(6) Aerial survey. An experimental survey of 40,000 acres was made, to test the possibilities of vertical photos (a) in reduction of amount of chain and compass work in forest mapping by ground parties, in addition to the usual assistance in laying out work in advance; (b) in providing low cost contour maps.

3. Abitibi Power \& Paper Co., Ltd.,-Iroquois Falls Division-reports:

(1) A study of brush disposal in a logging operation in a black spruce swamp was completed in February. An examination of the area will be made in the spring of 1930.

(2) A large area of unmerchantable black spruce swamp has been blocked off for a study in swamp drainage, much of the field work being done this year. The drainage ditches will be completed early in the spring of 1930 , and the area subjected to examination periodically.

The Sault Ste. Marie Division reports:

(3) Demonstration planting on burned areas in the Agawa river watershed.

(4) Continuation of sinkage study in conjunction with Woodlands Section of Canadian Pulp \& Paper Association.

\section{SASKATCHEWAN.}

1. Dominion Forest Service reports:

(1) Opening of a forest research station at Indian Head with a forester and pathologist. (a) The forester is establishing permanent sample plots in the plantations of the Tree Planting Division, some of which are 30 years old and now require thinning or other silvicultural treatment. (b) The problem of converting prairie shelter-belts to fuelwood lots is receiving 
consideration. (c) The pathologist is investigating canker in young poplar, a serious menace in shelterbelts.

(2) Investigations at Prince Albert in connection with the working plan for the Nisbet-Pines reserve indicate that it is not a simple matter to obtain jack pine reproduction following a logging operation, and the problem is being studied.

\section{ALBERTA.}

1. The Dominion Forest Service reports a continuation of the study of site classification in accordance with Cajander's theory.

\section{BRITISH COLUMBIA.}

1. The Provincial Forest Branch reports the following research during 1929:

(1) Aleza Lake Forest Experiment Station. Studies of establishment of spruce regeneration continued. Further experimental cuttings. Three new buildings to complete accommodation necessary for winter work.

(2) Cowichan Lake Station. Opened this year, with erection of buildings, although field studies have been under way here since 1927. An area of 400 acres planned as the headquarters for silvicultural research in the Douglas fir region. The main investigations during 1929 were:-(a) Continuation of study of mortality of seedlings of Douglas fir and associates. (b) Thinning experiment in 19-year-old stand of D. fir. (c) Construction of an experienced fire-line. (d) Trial of a chemical weed-killer for destroying fire-guard vegetation.

(3) Field studies in various parts of the province: (a) Annual examinations of history map areas. (b) Two important logging operations at Campbell river studied, making now 12 such areas under observation. (c) Routine annual remeasurements of the various permanent experimental plots. (d) Securing new data for mensuration studies from 41 new sample plots and strips. The main investigation concerned the application of existing yield tables to typical stands in the Provincial Forests. Diameter growth studies were carried out and the yield tables were given a practical field test in the Yahk Forest.

(4) Nurseries: (a) Victoria nursery. Main investigation a study of effect of seedbed density upon shoot and root development (b) New Westminster. An area of 620 acres set aside in 1929 for formation of a nursery and as a site for experimental plantations.

(5) Forest surveys:

(a) Preliminary working plan surveys totaling $1,694,000$ acres in four Provincial Forests (Interior). Examination standard one strip per mile from base lines five miles apart. Of the more important and extensive types there was found to be sufficient distribution of age classes as a result 
of fires to enable yield tables to be built up from the strip tallies. Maturity age and future production of immature stands of each type are being estimated. A study of existing local industries and present or expected future markets was made, and, in addition to an ultimate sustained yield estimate for each Forest, an annual cut is recommended for the next decade. The cut is calculated to bring the Forest towards a normal state with a minimum of interference with established demands on the timber. Protection plan being outlined, topographic and stand maps under preparation, etc., for above four Forests.

(b) Powell Forest. A proposed Coast Forest. Completion of inventory of 213,000 acres (greater portion of mature timber has been alienated, with cruises and maps available from the owners). The young growth is chiefly the result of logging during the last 30 years, so examination strips do not yield sufficient basis for yield tables.

Timber being logged is overmature, but stands estimated to be of the age and quality which will be merchantable in future have been measured and provide a basis for estimating yield from the young stands.

Coast Forests reports are planned as a guide to policy in dealing with the remaining Crown timber, reforestation of logged-off lands and improved protection, since there is not control over the cutting of alienated timber.

(c) Land classification in conjunction with above surveys as a basis for boundary definition. Five percent strip as basis for soil, topographic and cover maps. Data on forest cover, agricultural value, economic possibilities, etc., 184,400 acres.

(d) Survey of forest resources and preparation of the forest atlas of the province continued in 1929. Estimate for the Vancouver district available within a few months.

(e) Exploration reconnaissance of three million acres in upper Skeena River watershed as a possible Provincial Forest for pulpwood production.

\section{RESEARCH PROJECTS OF WOODLANDS SECTION OF CANADIAN PULP \& PAPER ASSOCIATION CARRIED ON IN 1929.}

(These given separately, as some of the work was done in more than one province).

(1) Woods labor: its efficiency and stability. A questionnaire was made by the Woodlands Section, besides which eight constructive reports were prepared by the member companies on this subject.

(2) Floatability of pulpwood and sinkage loss; continuation of a thorough investigation conducted by six member companies and two laboratories; to be completed in 1930 . 
(3) Improvements in chute logging: report containing suggestions for better and greater use of chutes.

(4) Possibilities of utilizing hardwoods for pulp and paper; field experiments and report dealing largely with economic transportation of birch by river drive.

(5) Efficiency of cutting wood with hand and motor saws; field experiments and report.

(6) Towing equipment: report on relative efficiency of the various tow. ing equipment used in pulpwood operations, based on numerous mechanical tests made in the course of this investigation.

(7) Experimental work in silviculture by member companies: reports made by foresters of several of the leading companies.

(8) Some research was done also in a number of minor projects.

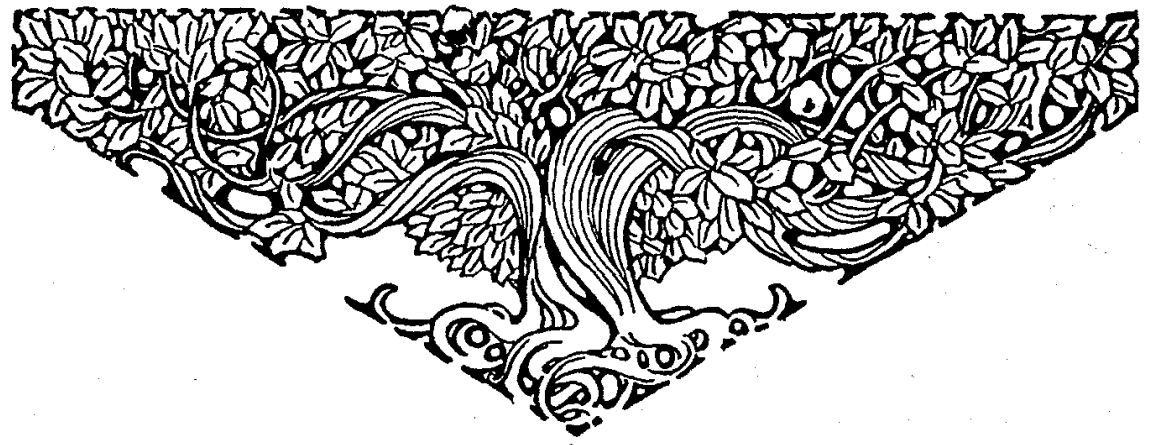

